DOI: $10.2478 / \mathrm{v} 10025-011-0004-6$

\title{
Natural conditions for the reconstruction of fish ponds and possibilities of their use in ecotourism
}

\author{
Bożena PRAJS ${ }^{1)}$, Maciej ROGALSKI ${ }^{2)}$, Zofia SOTEK ${ }^{1)}$, \\ Matgorzata STASIŃSKA ${ }^{1)}$
}

\author{
1) Department of Botany and Nature Protection, Szczecin University, ul. Felczaka 3a, 71-412 Szcze- \\ cin, Poland; e-mail: bajka@univ.szczecin.pl \\ 2) Department of Ecology and Environmental Protection, Szczecin University, ul. Wąska 13, 71-412 \\ Szczecin, Poland
}

\begin{abstract}
The paper comprises an analysis of the environmental impact of restoring small water retention in the Świergotka River. Hampering water flow due to river damming by $0.5 \mathrm{~m}$ and reconstruction of ponds will have a favourable effect on the valley's nature but may result in excessive water eutrophication in case of using these reservoirs for fish-farming.
\end{abstract}

Key words: pond management, protected areas, water retention

\section{INTRODUCTION}

Human interference in water conditions within the area of the Lower Odra River had started in a large scale in the 18th century and lasted, with different intensity, until the 20th century. In that time, the river course was changed, the riverbed was deepened, and polders surrounded by earth flood embankments were created within river valley. This was aimed at increasing river water discharge and elimination of backwater (ORLEWICZ, MROZIŃSKI, 2002). The changes affected also the flow parameters of smaller watercourses incorporated into the hydrological system of the Odra River. Within the area characterised by the lowest precipitation in the region (KOŹMIŃSKI et al., 2007) and being under intensive agricultural and forest management, the changes increasing the water discharge in the Odra River resulted in an increase of water deficiency in its catchment basin (KAJETANOWICZ, 1948). In order to counteract this unfavourable phenomenon, water reservoirs were built on many watercourses flowing into the Odra River and installations for water damming were constructed so that water energy would be economically used. Their traces have been preserved until the present days, although sometimes in the form 


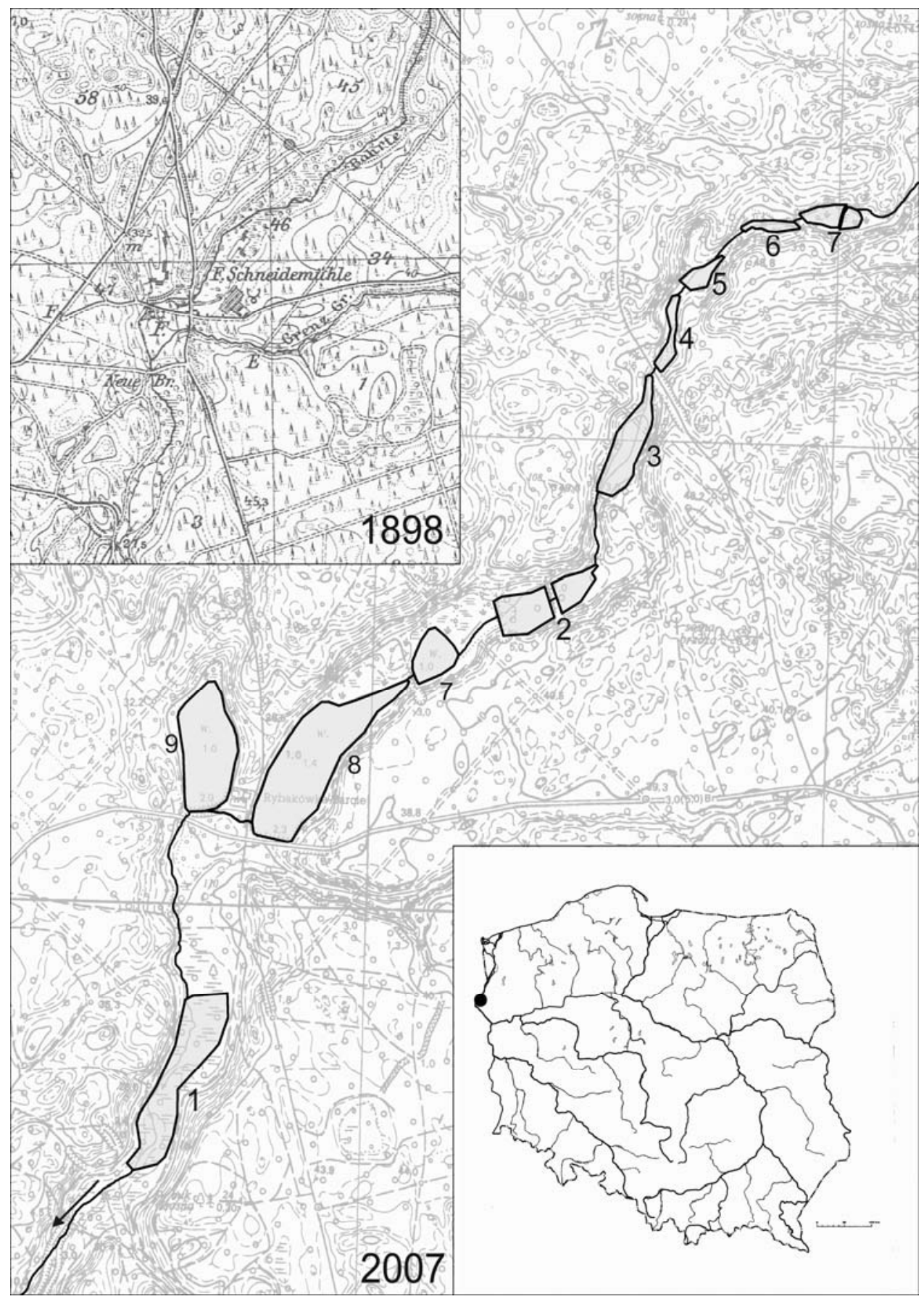

Fig. 1. Location of the study area; 7, 8, 9 - ponds filled with water; 1-6, 10 - number of dried ponds; $\leftarrow$ direction of water flow 
of village names on old maps, an example of which is the German name of a settlement - Schneidemühle (i.e. Sawmill) (Fig. 1). One of such places is the valley of the Świergotka River. Before the Second World War, the river current was dammed in 10 sections using natural valley widening, where fish ponds were formed. However, due to the destruction of damming installations and a decreasing level of ground waters, only three of them remained filled with water until recently.

In 2007, forest authorities obtained funds for the installation of hydrotechnical facilities to elevate water table by $0.5 \mathrm{~m}$ and to fill again seven drained ponds in order to restore old hydrological system within this section of the river.

The intended result was to increase retention capabilities of the river catchment basin and to improve habitat conditions of the valley. This created a necessity of plant cover examinations that would enable:

- evaluation of the value of currently developing ecosystems,

- prognosis of the dynamics of valley vegetation development under changed hydrological conditions,

- estimation of the risk of possible factors able to negatively influence the fluvial environment of the Świergotka River in its lower course.

This paper aims at analysing the effect of water storage on the nature of the Świergotka River valley.

\section{AREA DESCRIPTION AND METHODS}

The Świergotka River, part of the Odra River catchment basin, is placed within three protected areas - the Cedynia Landscape Park, the Natura 2000 Habitat Protection Area and Special Bird Protection Area. It emerges from an alimentation area situated $43 \mathrm{~m}$ a.s.1. and flows at $2.5 \mathrm{~m}$ a.s.1. into the relief channel that drains water from the plateau and the edge zone of the Odra River valley. The Świergotka River catchment basin area covers about 962 ha. The river flows in the valley with edges reaching a height of 10-20 m. Its width ranges from $15 \mathrm{~m}$ in valley gaps to $200 \mathrm{~m}$ in valley widenings, whereas the width of riverbed is about 1.5 $\mathrm{m}$. The bottom of watercourse is sandy but in widenings, where the current is slower, its bed is made up of a layer of mud. With the length of only $5.6 \mathrm{~km}$, the river is characterised by an average river fall about $7 \%$. The water flow varies from 0.1 to $0.15 \mathrm{~m}^{3} \cdot \mathrm{s}^{-1}$ and up to $0.5 \mathrm{~m}^{3} \cdot \mathrm{s}^{-1}$ in its lower course. The flow is generally determined by weather conditions and land surface. The Świergotka River has two right-side tributaries - upper one is connected with the headwater area by a ditch. In the lower course of the river, below the lower tributary, the water flows in a bed of steep-slope gorge incised into the plateau. The valley narrowing, mineral bed substrate, and increased water flow velocity make this fragment of the river similar to mountain watercourses in its physiognomy. Dry-ground forest Galio sylvatici-Carpinetum in the northern limit of distribution range of this community and 
beach forest Galio odorati-Fagetum developed there. Therefore, an area of 11 ha is protected as the "Dolina Świergotki" (the Świergotka River Valley) Forest Reserve.

Within a section from $1600 \mathrm{~m}$ to $4600 \mathrm{~m}$ of the upper and middle river course, fish ponds are situated in a cascade arrangement (Fig. 1). The total area of basins of these reservoirs is about $14.51 \mathrm{ha}$. The area of water table in three ponds filled with water is 2.55 ha, 4.29 ha and 0.70 ha. They are shallow reservoirs with a muddy bottom. The smallest of them is $0.5 \mathrm{~m}$ deep while the depth of two larger ones does not exceed $1.5 \mathrm{~m}$. The drained ponds cover 7.1 ha of the valley area.

Field investigations were carried out from June to October 2007. During the study, plant communities were localised and floristic lists were made. Particular attention was paid to the occurrence of: protected and endangered species (Rozporządzenie..., 2004), indicator plants for habitats specified in the Habitat Directive, and the existing and potential protected habitats (Ustawa..., 2004). The type of substratum and its water content were taken into account, apart from vegetation, when identifying potential habitats. Plant succession in the areas of former ponds was also determined as well as the advantages and possible environmental hazards associated with their re-use after river water damming by about $0.5 \mathrm{~m}$. The figure was made based on 1:10 000 topographic map and on 1:1 000 geodetic plans. Plant nomenclature was adopted after MIREK et al. (2002) and syntaxonomic affiliation was made according to MATUSZKIEWICZ (2002).

\section{RESULTS}

Managed forest stands, coniferous forests and mixed forests prevail in the Świergotka River catchment basin. They grow on russet soils developed on weak loamy sands or sandy loams. Plant cover of the examined section of the Świergotka River valley was largely formed under the influence of human activity. Also at present it is determined by the heterogeneity of habitat conditions and anthropogenic factors, i.e. historical settlement and land use in the form of pond farming and forest management. This influenced species richness, which is typically an important criterion in evaluation of the natural value of protected areas or those intended for protection.

Three ponds filled with water are important elements of the examined part of the Świergotka River valley in view of its both biocoenotic and landscape role (Fig. 1). Their littoral zone is covered by a mosaic of rush communities, i.e. Phragmitetum australis, Typhetum latifoliae and Sparganietum erecti and sedge rush (mostly Caricetum elatae, Caricetum acutiformis, Caricetum rostratae) developing from the north-western shore of the larger ponds and almost in the whole basin of the smallest reservoir. Intensive terrestrialisation is indicated there by the presence of numerous young alders. Water table is partly covered by nympheids 
Nupharo-Nymphaeetum and Potametum natantis as well as by duckweed communities. In the water depth, the following species were found: Ceratophylletum demersi, Elodeetum canadensis and Myriophylletum spicati.

With regard to physiognomy, ecosystems in the basins of old ponds are well isolated. Due to a lack of characteristic species, however, their phytocoenoses represent mostly regenerative or degenerative forms of natural communities associated with small river valley. Only patches of the following communities are clearly distinguished: Ribeso nigri-Alnetum, Sphagno squarrosi-Alnetum, Phragmitetum australis, Caricetum paniculatae, and Caricetum gracilis, as well as communities with Betula pendula, Molinia caerulea and Cardamine amara-Carex remota.

Ribeso nigri-Alnetum - grows on bottoms of old ponds in the Świergotka River valley (ponds 2, 3 and 6; Fig. 1) occupying wet eutrophic habitats characterised by water table variation due to hydrological regime of the river and dependent mostly on weather conditions. Within the tree layer, the community is formed by alders; it does not have valley-clump structure typical for the optimum stage and is characterised by considerable temporary partial drying manifested by the presence of forest and meadow species.

Sphagno squarrosi-Alnetum - acidophilous alder forest develops in the utmost north-eastern part of shoaled shore of pond 6 (Fig. 1). Tree stand is built by black alder Alnus glutinosa but there is characteristic participation of peat-mosses Sphagnum squarrosum and Sph. fallax in the floristic composition of undergrowth in depressions among trees. Also a considerable participation of forest species is observed there, as well as common rush, peat-bog and meadow plants.

Phragmitetum australis - reed bed patches develop in several places. They are mostly built by Phragmites australis with participation of other common rush species, e.g. Carex gracilis, Epilobium palustre and Lythrum salicaria. Desiccation of this community manifests itself by frequent presence of foreign species, as for example Rubus idaeus, Urtica dioica and even Calamagrostis epigejos and Pteridium aquilinum.

Caricetum paniculatae - community with a characteristic clumpy structure built by Carex paniculata occupies a small area in the northern part of pond 6 (Fig. 1) by a dike. Other patches are mostly situated in the north-eastern shoaled part of pond 4. Single clumps are also found in the valley periphery. $C p a$ is heavily transformed, overgrown with loose, fragmented fields of Carex gracilis, Phragmites australis, and Phalaris arundinacea. In some places, an expansion of Urtica dioica and Pteridium aquilinum is also observed.

Caricetum gracilis - common community of wet eutrophic depressions and meadows does not occupy larger areas within the examined site. Its patches are frequently found along watercourses, i.e. the Świergotka River channel and along artificial ditches excavated in its valley, as well as in alder forests. The community is composed of e.g. Ranunculus flammula, Equisetum palustre, Filipendula ulmaria, Lysimachia nummularia and Thelypteris palustris. 
Community with Betula pendula is an initial stage of the overgrowing of pond 5 (Fig. 1). In its tree stand, European white birch prevails with a small participation of alder and beech trees and of Salix cinerea. The undergrowth is rich and characterised by diversity typical for pioneer non-stabilised communities. It is built by such species as, for example, Phragmites australis, Carex gracilis, Deschampsia caespitosa, Cirsium oleraceum, Phalaris arundinacea and Urtica dioica. In many places, Rubus idaeus is frequently found.

Community with Molinia caerulea of an area of about $50 \mathrm{~m}^{2}$ is in the northwest part of pond 1. It is built by purple moor-grass Molinia caerulea with a tussock structure. Among grass tussocks and on them grow plants connected with wet meadows like Cirsium palustre, C. oleraceum, Ranunculus acris and Poa palustris. However, there are no species typical for and characteristic of this community, which shows that it is poorly and fragmentarily developed.

Community Cardamine amara-Carex remota has a form of poor two-species associations built by Cardamine amara and Carex remota in several places of the study area. Most frequently these are patches of an area less than several square meters growing on heavily watered peat substratum, where water seepages of the water-head character are observed (pond 5).

Non-stabilised phytocenoses of transitional character, which could not be clearly classified syntaxonomically occupy prevailing areas among communities. They represent a broad spectrum of occurrence in different synecological groups and are characterised by significant participation of widespread plants not classified phytosociologically. Participation of mostly meadow and forest plants and nitrophytes of wet and fertile habitats is typical for them. In almost all communities, several species of expansive post-timber felling plants spreading onto relatively dry, open and cleared places were observed (Fig. 2).

In total, the occurrence of 109 species of vascular plants, two species of peat-mosses and one species of liverwort (Marchantia polymorpha) was found within the examined area. No strictly protected taxa were found and only four species under partial protection, i.e. Frangula alnus, Ribes nigrum, Sphagnum fallax and Sph. squarosum. There were no endangered plants listed in the Habitat Directive (Ustawa..., 2004), in the "Polish Red Book of Plants" (ZARZYCKI and KAŹMIERCZAKOWA, 2001), in the red lists of endangered and threatened plants in the national scale (ZARZYCKI and SZELĄG, 2006) and regionally in Pomerania (ŻUKOWSKI and JACKOWIAK, 1995). 


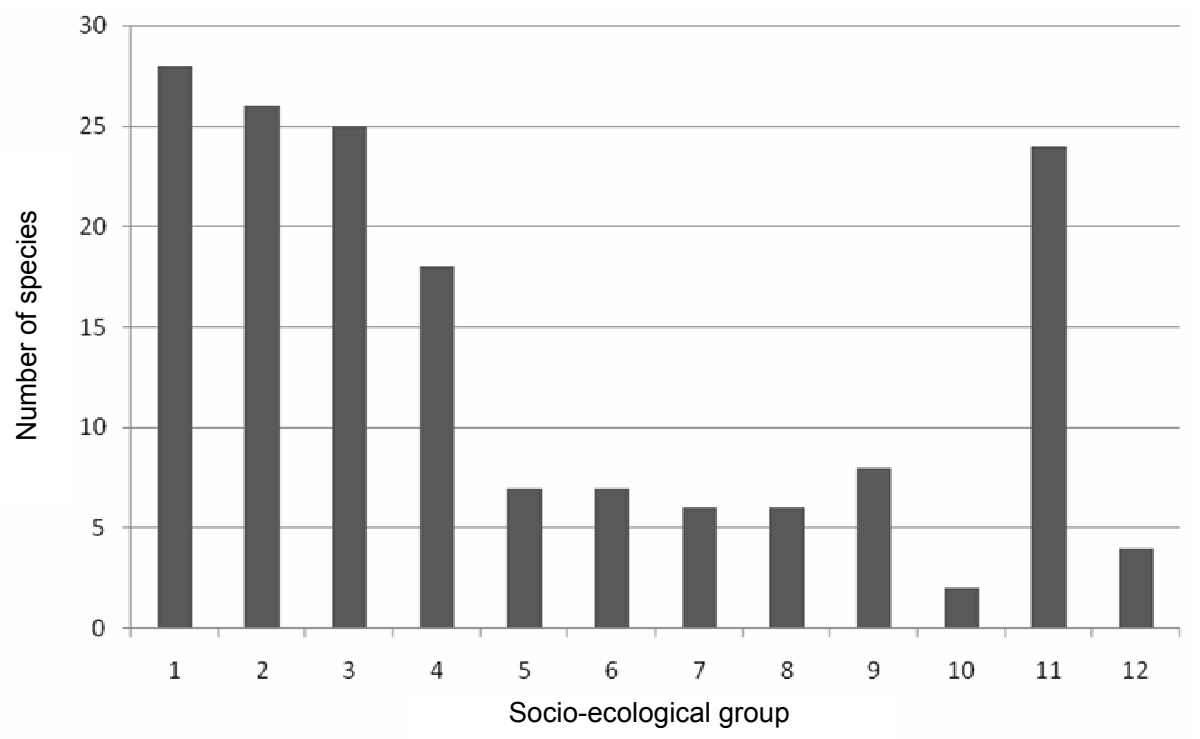

Fig. 2. Participation of socio-ecological groups in the vegetation cover of examined area. Species: 1 - meadow, 2 - hydrophytic and helophytic, 3 - woodland, 4 - waterbank nitrophilous and ruderal, 5 - bog, 6 - swampy alder forest, 7 - forest clearing, 8 - coniferoust forest, 9 - thermophilous shrubs, 10 - heathland, 11 - with undetermined syntaxonomic position, 12 - others

\section{DISCUSION}

When considering the purposefulness of interference in the existing hydrological conditions within protected areas, important biocoenotic function fulfilled by hydrogenic habitats and their value with respect to species diversity are taken into account. This diversity, however, is usually defined at the local level as the number of species and their relative abundance (Pullin, 2005). However, in relation to many habitat-specific ecosystems the diversity understood this way may reflect habitat destabilisation and the occurrence of vegetation in degradation or regeneration stages. Therefore, the presence of species typical for specific habitats should be also taken into account in evaluation, as well as rare species living as a rule in small populations or occupying small areas. They play an indicative role for well-preserved habitats (Ustawa..., 2004) and hence can be used for evaluation of the environmental quality.

Water retention, which as a rule is of positive importance in nature (KOWALEWSKI, 2004; MIODUSZEWSKI, 2006), may bring both positive and negative results in relation to rare taxa associated with local aquatic and wetland habitats. Enlargement of the area of stagnant and slow-flowing waters within this extensive forest complex will undoubtedly contribute to the formation of places fa- 
vourable for breeding and feeding of amphibians and birds (BAKER and HALLIDAY, 1999; WILLIAMS et al., 2008). On the other hand, reduction of the flow velocity induces changes in e.g. fish species composition - the species which lost suitable living conditions may disappear. Rheophilic fish are usually replaced by stagnophilic ones (BACKIEL, 1993). Such a change affects also the qualitative and quantitative relations of benthic fauna and other invertebrate species (ŻELAZO, 1993). Hampering water flow and its storage in ponds may also result in an increase of the trophic status in the river downstream reservoirs (LAMPERT and SOMMER, 2001).

Results of the study of plant cover in the Świergotka River valley indicate the lack of biotic equilibrium within wetland habitats due to their temporary excessive drying. At the bottom of this phenomenon observed in many places in the Lower Odra River catchment basin lies water deficiency caused by the lowering of ground water level and very low precipitation (KOŹMIŃSKI et al., 2007). This has resulted in fragmentation and disappearance of hydrogenic habitats which is, among others, one of the major reasons for elimination of water-related populations (GIBBS, 2000). At present, efforts are being made in the whole Europe to prevent this process, which is also unfavourable from the standpoint of agriculture and silviculture (Dyrektywa..., 2000; Biuletyn..., 2007).

Water retention in ten ponds will undoubtedly change present trends in the vegetation dynamics connected with the drying of habitats in the Świergotka River valley reflected in a considerable participation of meadow plants in forest peat-bog communities (with no communities from the class Molinio-Arrhenatheretea) and in abundant occurrence of nitrophytes within rush vegetation. Rising the water table by $0.5 \mathrm{~m}$ will limit the occurrence of sedge beds to the littoral zone. This will also eliminate initial communities of alder swamp forest and birch forest developing on the bottoms of some drained ponds. Reconstruction of ponds will contribute to a considerable enlargement of the area of communities associated with eutrophic reservoirs and to improvement of moisture conditions in forests situated in the valley. One may assume that this will elevate the ground water level (MIODUSZEWSKI, 2006) and improve microclimatic conditions of forest communities in the vicinity of the river.

It is extremely difficult, even impossible in many cases, to forecast the effect of undertaken water retention activities on flora and fauna. Therefore, for the sake of minimising possible negative habitat changes, in particular for animals, productive utilisation (i.e. fish production) should be excluded from these water reservoirs since it results in a significant increase of water eutrophication (BIEDROŃSKI, 2005). This is particularly important due to location of the "Świergotka River Valley" Forest Reserve in the lower course of the river, where rheophilic animal species may be found.

Nature protection often requires looking for compromise when confronted with human needs. Ponds located in the Natura 2000 Area - PLB 320017, within 
an extensive forest complex will create favourable conditions for fauna and improve the landscape. From the economic point of view, the use of such areas as a place suitable for ecotourism may be dealt with as a type of compensation. The Świergotka River valley situated in the area very abundant in avifauna enables spending time by observing and photographing birds, angling or making bicycle excursion around. Moreover, creation of conditions for relatively non-invasive human contact with the natural environment develops pro-environmental attitudes and is thought as one of the nature protection methods, particularly important in Natura 2000 sites.

\section{CONCLUSIONS}

1. Restoration of small water retention due to the reconstruction of historical ponds should improve natural conditions in the Świergotka River valley and, consequently, should increase biodiversity of this area.

2. Areas of hydrogenic habitats with fixed moisture level, being a favourable place for the living of fauna, will enlarge.

3. Filling the reservoirs with water again will elevate ground water level which is favourable for e.g. forest ecosystems.

4. Microclimatic conditions will improve, which is of great importance in areas with very low annual precipitation.

5. The ecological and landscape role of reconstructed ponds is superior to their possible productive functions which would result in excessive water eutrophication in the lower course of the river.

6. Formation of new water reservoirs can be used in developing nature-friendly forms of human activity.

\section{REFERENCES}

1. BACKIEL T., 1993. Ichtiofauna dużych rzek - trendy i możliwości ochrony. W: Ochrona przyrody i środowiska w dolinach nizinnych rzek Polski. (Ichthyofauna of large rivers: trends and possibilities of protection. In: Nature and environmental protection in the lowland river valleys of Poland). Ed. L. Tomiałojć. Kraków, Wydaw. Inst. Ochr. Przyr. PAN: 39-49.

2. BAKer J., HALliday T. R., 1999. Amphibian colonization of new ponds in an agricultural landscape. Herpetological Journal, 9: 55-63.

3. BIEDROŃSKI J., 2005. Zbiorniki małej retencji - problemy funkcjonowania. W: Problemy ekologii krajobrazu. (Small retention reservoirs - problems of functioning. In: The problems of landscape ecology). Eds. A. Szponar, S. Horska-Schwarz. Biul. PAEK, 17: 101-110.

4. Biuletyn Konferencji Ministerialnego Procesu Ochrony Lasów w Europie. 2007. Lasy i woda (Forests and water). art. 84, 3, Wydaw. Earth Negotiations Bulletin: www. iisd.ca/ymb/mcpfe5

5. Dyrektywa 2000/60/WF Parlamentu Europejskiego i Rady z dnia 23 października 2000 r. ustanawiająca ramy wspólnotowego działania w dziedzinie polityki wodnej. (Directive 2000/60/EC of the 
European Parliament and of the Council of 23 October 2000 establishing a framework for Community action in the field of water policy).

6. GiBBS J.P., 2000. Wetland loss and biodiversity conservation. Conservation Biology, 14(1): 314317.

7. Kajetanowicz Z., 1948. Hydrologia Odry. W: Monografia Odry. (Hydrology of the Odra River. In: A monograph of the Odra River). Eds. A. Grodka, N. Kiełczewska-Zalewska, A. Zierhoffer. Poznań, Instytut Zachodni: 215-267.

8. Kowalewski Z., 2004. Realizacja programów małej retencji w Polsce. (Implementation of small retention programmes in Poland). Zeszyty Naukowe AR Wrocław, 502, Inżynieria Środowiska, 12: $195-210$.

9. KoŹMiŃSKi CZ., MiChalsKa B., CZARNECKA M., 2007. Klimat województwa zachodniopomorskiego. (Climate of zachodniopomorskie voivodship). Szczecin, AR, USzczec.: 147.

10. LAMPERT W., SOMMER U., 2001. Ekologia wód śródlądowych. (Ecology of inland waters). Warszawa, PWN: $1-415$.

11. MAtUSZKIEWICZ W., 2002. Przewodnik do oznaczania zbiorowisk roślinnych Polski. (Guidebook for identification of plant communities in Poland). Warszawa, PWN: 1-537.

12. MiodUSZEWSKI W., 2006. Influence of small water reservoirs on ground water level. Teka Komitetu Ochrony Kształtowania Środowiska Przyrodniczego, 3: 136-140.

13. MiodusZEwSKi W., 2008. Mała retencja w lasach elementem kształtowania i ochrony zasobów wodnych. (Small retention in forests as an element of management and protection of water resources). Studia i Materiały Centrum Edukacji Przyrodniczo-Leśnej, 10, 2(18): 1-48.

14. MireK Z., PięKó́-Mirkowa H., ZająC A., ZająC M., 2002. Flowering plants and Pteridophytes of Poland - a checklist. Vol. 1. Ed. Z. Mirek. Kraków, Inst. Bot. im. W. Szafera PAN: 1-442.

15. ORLEWICZ S., MroziŃSKi Z., 2002. Hydrografia doliny dolnej Odry. W: Dolina dolnej Odry. Monografia przyrodnicza Parku Krajobrazowego. (Hydrography of the lower Odra valley. In: The Lower Odra River valley. A natural history monograph of the Landscape Park). Ed. J. Jasnowska. Szczecin, STN, Wydaw. ZAPOL: 67-89.

16. Pullin A.S., 2005. Biologiczne podstawy ochrony przyrody. (Biological foundations of nature conservation). Warszawa, PWN: 1-393.

17. Rozporządzenie Ministra Środowiska z dnia 09 lipca 2004 r. w sprawie gatunków dziko występujących grzybów objętych ochroną. (Decree of the Minister of Environment of 9th July 2004). Dz. U. nr 168 poz. 1765.

18. Ustawa z dnia 16 kwietnia 2004 r. o ochronie przyrody. (Nature protection act of 16th April 2004). Dz.U. Nr 92 poz. 880.

19. Williams P., Whitfield M., Biggs J., 2008. How can we make new ponds biodiverse? A case study monitored over 7 years. Hydrobiologia, 597(1): 137-148.

20. ZarzyCKi K., KaŹmierczaKowa R., 2001. Polska czerwona księga roślin. (Polish Red Book of Plants). Kraków Inst. Bot. im. W. Szafera., IOP PAN: 1-664.

21. ZARZYCKI K., SZEląG Z., 2006. Red list of the vascular plants in Poland. In: Red list of the plants and fungi in Poland. Eds. Z. Mirek, K. Zarzycki, W. Wojewoda, Z. Szelag. Kraków, Polish Academy of Sciences. W. Szafer Institute of Botany: 9-20.

22. ŻELAZO J., 1993. Współczesne poglądy na regulację małych rzek nizinnych. W: Ochrona przyrody i środowiska $w$ dolinach nizinnych rzek Polski. (Current views on the regulation of small lowland rivers. In: Nature and environmental protection in the lowland river valleys of Poland). Ed. L. Tomiałojć. Kraków, IOP PAN: 145-155.

23. ŻUKOWSKI W., JACKOWIAK B., 1995. Lista roślin naczyniowych ginących i zagrożonych na Pomorzu Zachodnim i w Wielkopolsce. W: Ginące i zagrożone rośliny naczyniowe Pomorza Zachodniego i Wielkopolski. (List of endangered and threatened vascular plants in Pomerania and Wielkopolska. In: Endangered and threatened vascular plants of Western Pomerania and Wielkopolska). Eds. W. Żukowski, B. Jackowiak. Poznań, Prace Zakładu Taksonomi Roślin UAM 3. Bogucki Wydaw. Nauk.: 9-96. 


\section{STRESZCZENIE}

\section{Mała retencja - analiza wpływu na środowisko i możliwości wykorzystania w ekoturystyce}

Słowa kluczowe: obszary chronione, retencja wody, użytkowanie stawów

Rzeka Świergotka, o długości ok. 5,6 km, uchodzi do kanału ulgi, na krawędzi Polderu Cedyńskiego. W okresie przed II wojną światową została spiętrzona na 9 odcinkach, na których powstały stawy. Na skutek zniszczenia urządzeń piętrzących tylko $3 \mathrm{z}$ nich wypełnione były wodą. W 2007 r. powstał projekt odtworzenia dawnego systemu retencyjnego. Stworzyło to konieczność wykonania badań szaty roślinnej i prognoz jej dynamiki w zmienionych warunkach hydrologicznych.

Badania prowadzono od czerwca do października 2007 r. Zlokalizowano zbiorowiska roślinne oraz wykonano spisy florystyczne. Określono także tendencje sukcesyjne roślinności na obszarach dawnych stawów oraz ewentualne zagrożenia dla środowiska przyrodniczego.

Ogółem na badanym terenie stwierdzono występowanie 109 gatunków roślin naczyniowych, dwa gatunki mchów torfowców i jeden gatunek wątrobowca. Nie odnotowano taksonów zagrożonych ani podlegających całkowitej ochronie, a jedynie cztery chronione częściowo. Na dnach dawnych stawów wykształciły się głównie olszyny bagienne lub zdegradowane zbiorowiska torfowisk eutroficznych, w których dominują pospolite gatunki wilgotnych łąk. Odtworzone stawy, ze względu na ryzyko znacznej eutrofizacji wód Świergotki w jej dolnym biegu nie mogą być wykorzystane jako hodowlane. Zlokalizowane na obszarze Natura 2000 - Ostoja Cedyńska PLB 320017, w obrębie rozległego kompleksu leśnego, są miejscem bytowania wielu gatunków ptaków. Przywrócony układ hydrologiczny pozytywnie wpłynie na różnorodność fauny, przyczyni się do zwiększenia areałów zbiorowisk związanych ze zbiornikami eutroficznymi oraz do poprawy warunków wilgotnościowych lasów doliny. Obszar ten może być wykorzystany do stosunkowo bezinwazyjnego dla środowiska kontaktu ludzi z przyroda. Wpływa to na kształtowanie postaw proekologicznych $\mathrm{i}$ jest jedną $\mathrm{z}$ ważnych metod ochrony przyrody.

Received 11.09.2009

Reviewers:

Prof. Waldemar Mioduszewski

Prof. Lestaw Wolejko 